Journal of Teacher Education for Sustainability, vol. 16, no. 1, pp. 76-88, 2014

\title{
The Finnish Five-String Kantele: Sustainably Designed for Musical Joy
}

\author{
Inkeri Ruokonen, Anu Sepp, Venla Moilanen, \\ Ossi Autio and Heikki Ruismäki \\ University of Helsinki, Finland
}

\begin{abstract}
This article discusses the five-string kantele as an example of the Finnish national heritage, a school instrument and an example of sustainable design. A qualitative case study was made by collecting the data from the Finnish students - prospective teachers - and the sixth form pupils, who had designed and carved their own five-string kanteles. The purpose of this research was to find out which aspects of five-string kantele design are considered the most important for sustainable principles and design among these youngsters. As results, the elements and principles of designing the five-string kantele are discussed and its relevance to five sustainable characteristics (creative, ecological, economic, aesthetic and socio-environmental) is presented. The sustainable values of the kantele and the purpose for which it is made are also considered.
\end{abstract}

Keywords: sustainable design, artifact, five-string kantele, musical instrument design, the Kalevala

\section{Introduction}

This paper discusses the five-string kantele as an example of sustainable design. The theoretical background discusses the role of the five-string kantele in the Kalevala and the cultural-ideological information that is conveyed through its use and construction. The principles and values of sustainable design are presented as well as contemporary design and research on the Finnish five-string kantele. The five-string kantele is an example of the Finnish national heritage, a heritage that has become a part of Finland's living musical culture in kindergartens and schools.

The five-string kantele is widely used in music education of Finnish preschools and primary education. Technical crafts and music education can be integrated by having students construct their own kanteles.

The education of national heritage and cultural history is an important part of Finnish basic education and forms part of the national core curriculum theme of cultural identity. The first part of the article will describe the kantele and its many roles: it is seen as the first invention; it is made for enjoyment and pleasure; it is used to convey information and for peaceful war making (concerning the fight for Sampo, only singing 
and the kantele are present in Pohjola). The music culture of schools and day care centers begins with teachers who create a musically rich living environment where singing, rhymes and kantele playing become part of students' everyday routines. At schools, the five-string kantele can be constructed by using creative, new design ideas so that music and technical crafts can easily be integrated in a creative design discussion. Finnish folk music and five-string kantele design and playing can also be easily integrated into various other activities like painting, movement, literature and drama.

The second part of this paper is the case study of students' conceptions of pupils who design and construct their own five-string kanteles, where they discuss the sustainable elements of the five-string kantele. In the Finnish National Core Curriculum (2004), "responsibility for environment, well-being and sustainable future" (p. 39) is a cross-curricular theme from the $1^{\text {st }}$ form to the $9^{\text {th }}$ form. The objective of Finnish basic education is to raise environmentally conscious citizens who are committed to a sustainable way of life. The pupils will learn to promote well-being in their own communities and understand that throughout their choices individuals construct both their own futures and the common sustainable future. The core contents of this theme are, for instance, ecoefficiency of production, design, society and everyday acting. Pupils are studying and discussing consumer behavior, their choices and actions concerning sustainability throughout their basic education years.

\section{The Sustainable Role of the Kantele in the Kalevala}

The history of the kantele is learned in schools to better understand its sustainable role in the context of the Finnish national heritage. The origins of this traditional, plucked string instrument can be found in the Middle East, but, as a member of the Baltic psalteries, the kantele is a unique instrument representing Finnish culture. Nowadays there are several types of kanteles; the largest version has 39 strings and a tuning mechanism, and it is used in folk music, classical and popular music (Ruokonen, Kattainen, \& Ruismäki, 2012).

The Finnish national heritage of folk music and poems, collected by Elias Lönnrot and published as the Kalevala in 1849, has become the national epic. The five-string kantele was decorated and first played by Väinämöinen, the hero of the Kalevala tale. The role of a kantele and music in the Kalevala is presented by analysing and reflecting on the text of the national epic by focusing on the poems where the five-string kantele is mentioned.

\section{“They Turned, They Listened to That Sweet Music, to the Kantele’s Eternal Joy”}

It has been estimated that approximately 2,500-3,000 years ago, a major new development in the culture of proto-Finnic groups living near the Gulf of Finland occurred. The result of this development, according to Asplund and Mettomäki (2000), was a unique form of song characterised by alliteration and parallelism as well as an absence of stanza structure. The poetic meter of these songs was a special trochaic tetrameter that is now often called Kalevala meter. When sung, the lines actually had four or five stresses and the melodies covered a narrow range, usually consisting of only five notes (Ruokonen et al., 2012). 
The archaic song tradition was a vital and living tradition throughout Finland until the 1500s. Some songs were recorded already in the 1600s, but most of the folk poetry collection work was carried out in the 1800s. The Kalevala epic is a collection of poetic song tradition sung in an unusual, archaic trochaic tetrameter, which had been part of the oral tradition of Baltic-Finnish languages for two thousand years. The Kalevala brought the small, unknown country and its people to the attention of other Europeans and strengthened its self-confidence in sustaining the Finnish language and culture. According to Asplund and Mettomäki (2000), the Kalevala has been translated into 51 languages in over 150 translations. In this paper, we refer to Keith Bosley's Oxford world classics translation from 1989. Bosley has, in a marvelous way, penetrated the singer's way of thinking and expressing thought and feeling in the images, music and rhythm of great poetry.

The oldest layers of folk poetry are represented by mythical poems that tell of creation acts as well as the origins of the world. Lyric songs express human, personal emotions. There are also ritual songs made especially for weddings and bear-killing feasts. The Kalevala meter incantations are verbal magic, which were a part of people's daily lives and activities. The main character in epic singing is usually a mighty singer, shaman and sorcerer, a leader who makes journeys to the land of dead in order to seek knowledge. The songs' heroes also have adventures in a distant land beyond the sea where they woo potential brides, make raids and flee the enemy. In the Finnish national epic, Kalevala, Väinämöinen is the main character who sings and plays the kantele. Väinämöinen searches the sea for Aino and catches her (she has been transformed to a fish) on a fishing hook. He loses her again and like most mighty heroes travels through many adventures.

There are two kanteles and two poems of the birth of kantele in the Kalevala and Väinämöinen has a major role in both of them. The first kantele was invented when three mighty Kalevala heroes, Väinämöinen, Ilmarinen and Lemminkäinen, set out to steal the Sampo, which is a pivotal element of the plot of the Finnish epic poem. According to the Kalevala, he who possesses the Sampo receives prosperity and all good things. Ilmarinen, the smith of the Kalevala, had created the Sampo, but it was given to the Pohjola (Northland, a location in Finnish mythology) in ransom for the return of the maiden of Pohjola, who was Mistress of Pohjola's (Louhi's) daughter. The tale is like a fisherman's tall tale. In the course of the journey to Pohjola, the boat of the three heroes runs aground on the shoulders of a giant pike. Väinämöinen kills the pike and fashions a kantele from this jawbone. No one else is able to play the instrument, but mighty Väinämöinen holds all living things spellbound with his playing. Thus, the kantele was a new invention, the first instrument to produce sound in the air. The music Väinämöinen played was so powerful that all creatures in nature wanted to listen to it, "There was none in the forest running on four legs or hopping on foot that did not come to listen marvel at the merriment ... the air's nature daughters and the air's lovely lassies marvelled at the merriment, listened to the kantele ... there was no creature not in the water either moving with six fins the best soul of fish that did not come to listen" (The Kalevala, 1849/1989, pp. 539-541). 


\section{Sustainable Power of Kantele Music in Peace Making}

The Kalevala men want to share the Sampo with Northland (Pohjola), but Louhi, the mistress of Pohjola, refuses and calls her young men together with their swords and weapons to kill Väinämöinen. What did old Väinämöinen do? He had no weapons or swords; he just began to play music with the kantele. This power of music is used instead of weapons, "Steady old Väinämöinen seized his kantele, he sat down to play and began to play prettily; and they all stopped to listen and marvel at the merriment - men in good spirits, wives with smiling lips, fellows with tears in their eyes and boys kneeling on the ground. He wears the folk down and tires the people: all the listeners fall asleep; the watchers sank down; the young slept and the old slept at the sound of Väinämöinen's music" (The Kalevala, 1849/1989, p. 548).

Väinämöinen puts the people of Pohjola to sleep with his kantele playing. The Sampo is taken to the travelers' boat, and they row away. Therefore, the war was peacefully over, or so the heroes of Kalevala thought. When the people of Pohjola awaken, Louhi sends obstacles in the path of the sailors to hinder their escape. The seafarers survive, but the first pike bone kantele falls into the sea. Louhi sets off in pursuit and transforms herself into a giant bird of prey. In the ensuing battle, the Sampo is also smashed and falls into the sea, but others wash ashore and bring Finland good fortune and prosperity. In vain, Väinämöinen seeks the kantele, which had fallen into the sea.

\section{Sustainable Value of Joy and Creativity in Kantele Music}

Väinämöinen makes a new kantele from weeping birch wood, "Here is a belly for the kantele, a soundboard for eternal joy" (The Kalevala, 1849/1989, pp. 579-580). Nearby there was an oak, and, on its acorn, was a golden whorl and a cuckoo; every time the cuckoo calls and utters five words, gold and silver wells from its mouth on a golden knoll on a silver hill and from there Väinämöinen gets the screws for the kantele. Still, five strings of the kantele are missing and Väinämöinen begs for tresses from the hair of a young maiden, Aino, "Lass, give me some of your tresses, damsel, of your hair for kantele strings voices of eternal joy!'(The Kalevala, 1849/1989, p. 581). The maiden gave some of her tresses and the new instrument was ready. Väinämöinen plays music again and delights the whole creation; this music was characterised as even more beautiful than the sound of the first kantele, "Never have we heard such playing, never heard such strains of music, never since the earth was fashioned, as the songs of this magician, this sweet singer, Väinämöinen!” (The Kalevala, 1849/1989, p. 582). At the end of the Kalevala epic, a poem symbolises the coming of the new Christian era to Finland. Marjatta conceives a child from a whortleberry. Väinämöinen condemns the fatherless child to death, but the child speaks out against the sentence and is christened King of Karelia. Väinämöinen departs in a copper boat with the prediction that he will be needed again someday to make a new Sampo for the people to bring happiness, new light and new songs. He also leaves his kantele and Kalevala songs for Finnish children to sing throughout all times and places. "Then the old Väinämöinen goes full speed ahead in the copper boat, the coppery punt to where mother earth rises and heaven descends and there he stopped with his craft with his boat he paused; but he left the kantele behind the fine music for Finland for the folk eternal joy the great songs for his children" (The Kalevala, 1849/1989, p. 663). 
So the role of the kantele in the Kalevala is first as a new invention, a totally new man-made creation, the first instrument ever developed; secondly, the kantele plays an important role as music was a new way to describe emotions so the role of the kantele is to make music for pleasure and joy for all of creation. The kantele had also a peaceful role in a war; it was used instead of weapons. The role of music was also therapeutic and relaxing. The role of music in distributing information is seen throughout the Kalevala. The kantele also had a role as maintainer of creative traditions. That is, the birth of new songs and ways to use the instrument was based on the tradition of folk music singing, playing styles and improvisation. At the end of the Kalevala, Väinämöinen speaks about changing and developing tradition, "Just let the time pass, one day go, another come, and again I'll be needed... make a new music, convey a new moon, set free a new sun ...” (The Kalevala, 1849/1989, p. 663).

\section{Role of the Five-String Kantele in Finnish Education}

The present study concerns the educational design and focuses especially on sustainable design in Finnish culture. Therefore, the role of the kantele in Finnish education as well as design practices and its development in Finnish kantele design is introduced.

The five-string kantele was about to disappear from Finnish education in the early 1950s, but, nowadays, it has an important role in Finnish music culture and education. Several factors influenced this rise in interest in the kantele. Firstly, a new interest in Finnish folk music began in the village of Kaustinen, where the first Folk Music Festival took place in 1968. Secondly, Professor Martti Pokela worked on folk music in the Sibelius Academy and in music teacher education during the 1970s and 1980s; he established the folk music department in the Sibelius Academy in 1983 together with professor Heikki Laitinen (Ruokonen, 2003).

The original playing style of small kanteles from the Savo and Karelia areas has survived until today. In that style, the hands rest against both sides of the instrument. The strings are never damped, except in some cases to produce special sounds, so they can ring as long as possible or until they are played again. That makes the sound lasting longer and creates a hum and rattle - an important element of the musical tissue (Laitinen, 2010b).

Because of the variety of kanteles, there are also many other playing techniques today. The five-string kantele is a great instrument to begin with because of its suitable size, gentle sound and tuning close to the central register of the human voice $(\mathrm{d} 1-\mathrm{a} 1)$. Playing a chord is also quite easy, even for small children, so the kantele makes playing fun and interesting.

Playing the five-string kantele began in the kindergartens and schools in the 1980s. The so-called "berry chords" ( $\mathrm{I}=$ strawberry, V=blueberry, IV=cloudberry), which are, nowadays, commonly used, were invented by kindergarten teacher, Maija Simojoki, who also published the first kantele tutorials together with Ritva Ollaranta. In early music education, the five-string kantele has become one of the most popular instruments. It can be used as an accompaniment instrument, played by the teacher, or played by the children. The kantele can be played even in infant music groups, but it is most commonly used with the children aged six years and older (Ruokonen et al., 2012; Tenhunen, 2010). 
According to Ruokonen et al. (2012), the kantele is a part of a journey to the sources of creativity. Improvisation has always had an important role in the kantele tradition. The magical sound of the instrument helps the musician to let the music flow freely. Laitinen (2010a) describes how hundreds of people of all ages, who had never played any instrument, became enchanted by the five-string kantele in the 1980s, when a project on behalf of the kantele was started. The people touched the strings carefully one by one so that new sounds filled the air and suddenly there was an infinite number of melodies and original music. It was impossible for them to stop playing. Laitinen (2010a) acknowledges that there is a complete alternative music pedagogy hidden in the kantele. According to Hill (2005), Finnish contemporary folk musicians have created a new, innovative, passionate, diverse, self-consciously artistic design and form of music.

In the present Finnish National Core Curriculum (2004) for basic education, music and crafts are a part of the arts. Craft is divided into technical and textile crafts. According to Sepp, Ruokonen and Ruismäki (2010), the whole concept of arts as well as arts education has many meanings and connections and is not easy to define perfectly: it encompasses the development of affective, cognitive, technological, psychomotor, social skills as well as specific subject knowledge. According to Autio, Thorstenseinsson and Olafsson (2012), the aim of Finnish craft education is to increase pupils' self-esteem by developing their skills through enjoyable crafts activities and increasing their understanding of the various manufacturing processes and the use of different materials in craft. Finnish handicraft traditions are also important throughout the whole curriculum (Framework Curriculum guidelines, 2004).

Ruokonen and Muldma (2007) have researched the sustainable and cultural meanings of music in basic education through the 8th form pupils' thoughts and experiences. Their study indicates that Estonian and Finnish the 8th form pupils see music as an essential value. The kantele is played at schools in both countries, and pupils considered music education to be a part of their culture and cultural education. Music also had important cultural and educational roles for sustainable development in both countries. The meanings of music were connected to the values of recognising diversity and increasing the respect and tolerance for differences. Music also promoted the creativity of pupils in a spirit of freedom and intercultural dialogue (Ruokonen \& Muldma, 2007).

\section{Design and Development of the Finnish Five-String Kantele}

Designing and constructing the five-string kantele is very popular and valued in Finnish instrumental design culture nowadays because of the important role of the kantele in Finnish music culture and education. Many companies, private designers, students pupils construct their own creative versions of a five-string kantele.

According to Hienonen (2007), the success of a new design product is connected to the designer's ability to feel and give birth to new ideas that provide positive experiences, services and products for people. For instance, the Koistinen Company has had the mission to update the instruments' old image to a modern look and sound by developing the Wings kantele (Koistinen, 2014a, 2014b). The product graphics collection was designed in two parts accordingly. The ideas for the design are chosen from the Kalevala epic, folk-tales, Karelian embroidery and Finnish nature. 
It is easy to produce an electronic version of kantele by adding microphones to it. In schools, acoustic kanteles are primarily used in pre- and primary schools and electronic versions in higher grades.

Nowadays Finnish kanteles are more often seen in concerts and in situations where players are before a large audience, but the traditional Finnish models are usually not heard without amplification. Although there are electronic versions of the kantele and microphones for kanteles on some occasions, they do not serve the musical presentation. On the stage, the kantele needs to be louder than traditional models, and this has been examined by researchers from the Helsinki University of Technology in co-operation with the Leppävirta kantele company. Pölkki, Erkut, Penttinen, Karjalainen and Vesa Välimäki (2003) have developed a new design for the kantele according to what can be done without electrical amplification. They had the idea to add a freely vibrating top plate to an 11-string kantele from the old five-string museum kanteles: some of them have a closed box while others are carved from a single piece of wood so that they have a top with sides along the edges, but no bottom. The bottomless design is clearly the louder of the two, and it has a warmer timbre. Their practical experiments showed that the old bottomless design could be further improved by taking the idea of a "bottomless box" to the direction of a reinforced plate. An experimental bottom, fixed to the top at the center and separated with a small gap at the boundaries sounded louder and was used in their design improvement and research (Pölkki et al., 2003).

Other researchers in the field of kantele design and construction have added other ideas to this discussion. Penttinen's (2006) future dream of kantele design is to be able to accomplish instrument design in the digital domain. This means building and reshaping an instrument on the computer by listening to how the changes affect the final instrument before a single finger has even touched wood. Kastinen (2000) lifts up the aesthetic features of an artistic experience by stressing that the subjective qualities of sound are not the same as its physical parameters. Loudness, pitch and timbre are all more or less dependent on pressure, frequency, spectrum, duration and envelope (Kastinen, 2000).

\section{Some Principles of Sustainable Design}

The concept of sustainability appears in several texts with many different definitions. Broadly, the content of the concept is determined by the different value criteria of the various interest groups around an object or a product. According to McLennan (2004), sustainable design, as the design component in a sustainability philosophy, can be seen as a practice by a growing number of people who understand and accept the sustainability premises, as outlined in the following section. Sustainable design is the philosophy of designing physical objects, the built environment and services to comply with the principles of social, economic and ecological sustainability (McLennan, 2004). Alting, Hauschild and Wenzel (1998) connect sustainability to the economic, social and environmental responsibilities of people in the future in maintaining resources that will continue to serve people's needs.

Few written research articles exist that discuss the principles of sustainability concerning musical instruments. One has to look at other areas of design products. For instance, design-based, green engineering principles of sustainable design can be used more widely than only in science and technology. The 12 principles of sustainable design move beyond baseline engineering quality and safety specifications to consider environ- 
mental, economic and social factors and can be used in creating and describing any design product. The first four green principles are as follows. Firstly, designers need to strive to ensure that all material and energy inputs and outputs are as inherently nonhazardous as possible. Secondly, it is better to prevent waste than to treat or clean up waste after it is formed. Thirdly, separation and purification operations should be designed to minimise energy consumption and materials use. Fourthly, products, processes and systems should be designed to maximise mass, energy, space and time efficiency. The next principles continue to detail the many aspects of sustainable design. Fifthly, products, processes and systems should be "output pulled" rather than "input pushed" through the use of energy and materials. Sixthly, embedded entropy and complexity must be viewed as an investment when making design choices to recycle, reuse, or beneficially dispose of materials. Seventhly, targeted durability, not immortality, should be a design goal. Eighthly, designs should be tailored to fit needs rather than for unnecessary capacity or capability (for instance, “one size fits all”). The last four principles lead to green and sustainable thinking in designing the products. Ninthly, material diversity in multicomponent products should be minimised to promote disassembly and value retention. Tenthly, the design of products, processes and systems must include integration and interconnectivity with available energy and materials flows. Eleventhly, products, processes and systems should be designed for performance in a commercial "afterlife", and, finally, material and energy inputs should renew rather than deplete resources (Anastas \& Zimmerman, 2003).

Although the five-string kantele was not originally conceived to encompass all of these twelve principles of sustainable design, it can be seen as a design product that incorporates Benyus' (1997) ideas of biomimicry design. According to Benyus (1997), nature can be seen as a model, and designers can find inspiration for designs in nature; they also use the ecological standard to judge the correctness of their innovations and value what they can learn from nature.

\section{Research Design and Methodology}

Creativity and innovations in society require competencies that develop through participation and group work. These processes that develop through collaborative work with knowledge and solving problems is called knowledge creation (Bereiter, 2002; Hakkarainen, Palonen, Paavola, \& Lehtinen 2004). According to Seitamaa-Hakkarainen (2011), design learning provides students important opportunities to work with design task in authentic and meaningful collaborative learning contexts where they can share and develop their new creative ideas of design. Because the design activity happened in collaborative learning settings, the group interview was a natural choice for data gathering in this case study. According to Stake (2006), a case study attempts to understand particular nuances about a case, which, in this study, involves the kantele designing experiences of the pupils and prospective teachers.

The aim of this qualitative case study was to determine which sustainable features Finnish young people can find in the five-string kantele as a design product. The aim was to discuss the sustainable features in the design of the five-string-kantele through group interviews of five prospective teachers and five $6^{\text {th }}$ form pupils who had experiences of carving and designing five-string kanteles for themselves. They were asked to consider which elements and principles of the design of the five-string kantele have made it so 
good and sustainable that it has been a part of Finnish culture for so long. The group interviews were made at the University of Helsinki, Department of Teacher Education and with five $6^{\text {th }}$ form pupils from a Finnish comprehensive school in the Helsinki metropolitan area. The group interviews were made after their kantele design project when their kanteles were ready for playing. The questions asked both groups were the following: Which aspects of five-string kantele design do you consider the most important for sustainable principles and design; What is your opinion of the elements and principles of designing the five-string kantele and What can you tell about the design process of your own kantele? Finnish school children are used to discuss about the sustainability because of the cross curricular theme "Responsibility for environment, well-being and sustainable future" in the Finnish National Core Curriculum 2004. According to Cohen, Manion and Morrison (2011), group interviews are useful choice when a group of people have been working together for some time or a common purpose. In this case, both arguments were true, and, when discussing sustainability and design, it was important to share the experiences and ideas that were presented during the collaborative work.

In this research, we were interested in identifying the sustainable design elements of the five-string kantele. Group interviews began by looking at and playing five-string kantele with a brief discussion of some general features existing in this instrument and by discussing how interviewees describe the term sustainable design. In both groups of interviewees, students and pupils had constructed their own designs of a five-string kantele. These new models were compared with the traditional ones and with each other by discussing which features they wanted to maintain in their own kantele design and which variations they made and why. During the group discussion, they introduced the type of five-string kanteles they had designed, and they named the five most important features of sustainability for five-string kanteles in general. The actual group interview focused on the subjective experiences of the participants and their varied and common opinions about the design process and sustainable design. The group interviews were recorded, and the transcribed form of interviews were listened to and read several times to provide a context for the specific units of meanings which were identified and qualitatively analysed by finding different aspects of sustainability. The group interviews were qualitatively analysed and classified to five themes found from the basic data.

\section{Research Findings}

As a result, the features of sustainable design of five-string kanteles are presented as these ten young Finnish prospective teachers and pupils describe them. According to these interviews and the views of Finnish young people, the sustainable features of fivestring kantele design were classified in five dimensions.

At first, the creative values of the five-string kantele were discussed. The five-string kantele was seen as a musical instrument that is optimally easy to play and improvise so it increased the willingness of the player to invent melodies and playing styles and improvise. This was seen as an important sustainable value of creating joy and increasing creativity in the mind. The five-string kantele allowed for an individual's own musical design. The visual and shapely creativeness was also used in constructing and decorating their models of the kantele. One student mentioned that, "I looked at the old model of the kantele in the National Museum and used it in my model, but I wanted to decorate it somehow in a tattoo style." (6th form pupil) 
The ecological aspects were discussed as a feature of sustainable design. Finland is famous for its forests, and the kantele is made from wood - a natural material that is very familiar to Finns. Wood, usually black alder, is easy to carve and use again if needed. One prospective teacher suggested, "The five-string kantele has a sustainable future in Finland; we should teach more wood-carving in our schools." In this feature, nature could be seen as an essential element of design.

Also, economic values were discussed as an element of sustainability. The fivestring kantele is an inexpensive instrument of natural material and it is even less expensive if people make it themselves. The instrument is also easy to make at school and fits well in a curriculum of technical crafts. One student noted, "For me this was the best part of my craft studies. I could plan the form of my piccolo five-string kantele, and I only had to pay for five metal strings and some metal parts (ponsi and varras) of my kantele, so I saved a lot of money. I could also have a personal bird design on my kantele." Thus, the natural design and material of the kantele shows that it can be ecologically designed and that process enhances creativity.

An aspect of sustainability found in these discussions was a social aspect in a craft class where wood was carved and the visual ideas of design were shared. When the instruments were ready, the musical joy of playing the kanteles and singing together was shared. One pupil described this enthusiasm, "The atmosphere was high when we first tuned our kanteles and started to play and realised that these are real instruments we have designed and made." (6th form pupil)

Another sustainable aspect discussed was aesthetic or musical. The interviewees mentioned the sound of the kantele as one of the features of sustainable design. They valued the quiet sound of the kantele and, especially according to the prospective teachers' opinions, this was a real sustainable value in a world, which one teacher described as full of "loud, global sound pollution enfolding us everywhere". This was a very interesting opinion to consider when the kantele companies are now developing and researching new design forms to produce a louder kantele. The aesthetic features of the visual design and its effect on sound production were also mentioned. The individual beauty of design was also seen as a sustainable value. The old Kalevala spirit of kantele was also seen as an aspect of sustainability. The kantele is the only instrument with such a long history in Finnish culture and this was seen as a very sustainable feature, as expressed by one prospective teacher, "The spirit and beauty of Kalevala style singing is touching contemporary singers. Many singers and players also compose new music from the old tradition."

Figure 1 outlines the main aspects of sustainable design that can be seen in the modern use of the kantele. 




Figure 1. Features of sustainable design of the five-string kantele

\section{Discussion and conclusions}

According to this study, the five-string kantele can be used as a tool of learning Finnish national heritage and cultural history as well as an instrument in music education and a design artefact in crafts education. These characteristics can be used to promote different forms of sustainable education. The examination of the Kalevala shows that, in Finland, the five-string kantele, firstly, had a role as an invention; secondly, as an instrument to provide enjoyment and pleasure and, thirdly, as a means of distributing information and, finally, as a means of promoting a peaceful lifestyle. The elements and principles of the design of the five-string kantele show that this sustainable design object consists of visual, musical, creative, aesthetic compositional elements. The five-string kantele is an old invention, and, somehow, by looking at it and its new forms, we can see that nature is a Finnish mentor. The kantele introduces people to an era-based musical tradition, and the instrument can also be designed in many new ways, so it shows people what can be learned from nature and cultural heritage, how it can be used in creative ways in Finnish culture and education now and in the future.

Design learning and participation in the artistic integrative activities create capabilities for students to be part of surrounding society and think about its sustainable design. Integration crafts and music education for sustainable education provides a possibility for collaborative learning. Sustainability is discussed, adapted and developed in a concrete way in an integrative process in which students become creative problemsolvers and designers of their own model. The sustainable aspects of kantele are found in its cultural spirit and old Kalevala tradition, which has to be learned and transformed. Moreover, five-string kantele is pedagogically very practical and easy to use in new creative ways at school. The Finnish National Core Curriculum for Basic Education as 
well as the Curriculum of Teacher Education provides a lot of possibilities to apply integrated curriculum to implement education for sustainability, particularly via educational design learning projects.

\section{References}

Alting, L., Hauschild, M., \& Wenzel, H. (1998). Elements in a new sustainable industrial culture Environmental assessment in product development. Robotics and ComputerIntegrated Manufacturing, 14, 429-439.

Anastas, T. P., \& Zimmerman J. B. (2003). Design through 12 principles of green engineering. Environmental Science \& Technology, 1, 95-101.

Asplund, A., \& Mettomäki, S. L. (2000). Kalevala - the Finnish national epic. Retrieved November 12, 2011, from http://virtual.finland.fi/finfo/kaleva.htm

Autio, O., Thorstenseinsson, G., \& Olafsson, B. (2012). A comparative study of Finnish and Icelandic craft education curriculums and students' attitudes towards craft and technology in schools. Procedia Social and Behavioral Sciences, 45, 114-124.

Benyus, J. M. (1997). Biomimicry. Innovation inspired by nature. New York: Perennial.

Bereiter, C. (2002). Education in mind of knowledge age. New Jersey. NewYork: Erlbaum.

Cohen, L., Manion, L., \& Morrison, K. (2011). Research methods in education (7 $7^{\text {th }}$ edition). New York: Routledge.

Finnish National Core Curriculum. (2004). Helsinki: Finnish Board of Education.

Framework Curriculum Guidelines. (2004). Helsinki: Finnish Board of Education.

Hakkarainen, K., Palonen, T., Paavola, S., \& Lehtinen, E. (2004). Communities of networkers expertise. Professional and educational perspectives. Oxford: Elsevier.

Hienonen K. (2007). Suomalaisen designin uudet mielentilat [New tempers of Finnish design]. Keuruu: Otava.

Hill, J. L. (2005). From ancient to avant-garde to global: Creative processes and institutionalization in Finnish contemporary folk music (Unpublished doctoral dissertation). University of California, Los Angeles, the US.

Kastinen, A. (2000). Erään 15-kielisen kanteleen akustisesta tutkimuksesta [An acoustical investigation of a 15-string kantele] (Unpublished doctoral dissertation). Sibelius Academy, Helsinki, Finland.

Koistinen, M. (2014a). Viisikielisen kanteleen valinta: Easy Wing 5 [Choosing the fivestring kantele: EasyWing 5]. Retrieved August 7, 2014, from http://www.koistinen kantele.com/fi/kanteleen+valinta/\#0

Koistinen, M. (2014b). Modern. Koistinen kantele. Retrieved April 3, 2014, from http://www.koistinenkantele.com/en/shop/kanteles/modern

Laitinen, H. (2010a). Kanteleen ibme [The miracle of the kantele]. In R. Blomster (Ed.), Kantele (pp. 11-19). Helsinki: Suomalaisen Kirjallisuuden Seura.

Laitinen, H. (2010b). Kanteleen historian käännekohtia [Turning points in the history of the kantele]. In R. Blomster (Ed.) Kantele (pp. 121-166). Helsinki: Suomalaisen Kirjallisuuden Seura.

McLennan, J. F. (2004). The philosophy of sustainable design.Kansas City: Ecotone.

Penttinen, H. (2006). Loudness and timbre issues in plucked stringed instruments analysis, synthesis, and design (Doctoral dissertation). Retrieved from https://aaltodoc.aalto.fi/handle/123456789/2735? show=full 
Pölkki, J., Erkut, C., Penttinen, H., Karjalainen, M., \& Vesa Välimäki (2003). New designs for the kantele with improved sound radiation. Proceedings of the Stockholm Music Acoustics Conference (pp. 1-4). Stockholm: SMAC03.

Ruokonen, I. (2003). The Kantele, our national heritage - "among the youngsters rising among the people growing”. In Neothemi Conference 2003 Proceedings (pp. 192203). Helsinki: Yliopistopaino.

Ruokonen, I., \& Muldma, M. (2007). "What music means to me": Estonian and Finnish eighth-grade pupils' opinions on music. Education and Sustainable Development: First Steps towards Changes (Vol. 2, pp. 175-190). Daugavpils: Daugavpils University Publishing House "Saule".

Ruokonen, I., Kattainen, A., \& Ruismäki, H. (2012). Preschool children and the five-string kantele: An exercise in composition. Procedia Social and Behavioral Sciences, 45, 391-400.

Seitamaa-Hakkarainen, P. (2011). Design based learning in crafts education. In H. Ruismaki \& I. Ruokonen (Eds.), Design learning and well-being: $4^{\text {th }}$ International Journal of Intercultural Arts Education (pp. 3-14). Helsinki: Unigrafia.

Sepp, A., Ruokonen, I., \& Ruismäki, H. (2010). Comparing some aspects of Estonian and Finnish music educational systems and curriculum. In H. Ruismäki \& I. Ruokonen (Eds.), Rights of the child to the arts, culture and creativity: $2^{\text {nd }}$ International Journal of Intercultural Arts Education (pp. 3-22). Helsinki: Yliopistopaino.

Stake, R. E. (2006). Multiple case study analysis. New York: Guilford Press.

Tenhunen, A.L. (2010). Kanteleen nykynäkymiä [Contemporary views on the kantele.] In R. Blomster (Ed.), Kantele (pp. 295-307). Helsinki: Suomalaisen Kirjallisuuden Seura.

The Kalevala (K. Bosley, Trans.). (1989). Oxford: Oxford University Press. (Original work published 1849).

Correspondence concerning this paper should be addressed Inkeri Ruokonen, PhD, Department of Teacher Education, Faculty of Behavioural Sciences, the University of Helsinki, Box 800014, the University of Helsinki. Email:inkeri.ruokonen@helsinki.fi 